POLIIICAL ECONOMY RESEARCH INSIITUTE

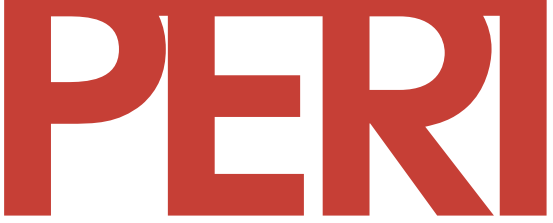

University of Massachusetts Amherst

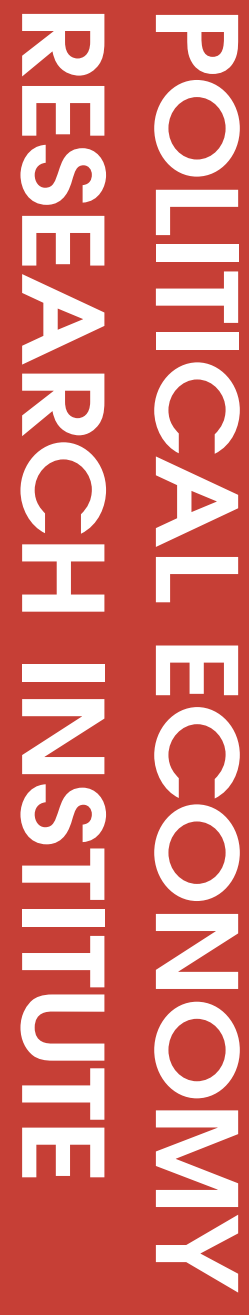

Nasrin Dalirazar

\title{
An Econometric Analysis of International Variations in Child Welfare
}

2003

10th floor Thompson Hall University of Massachusetts Amherst, MA, 01003-7510 Telephone: (413) 545-6355 Facsimile: (413) 545-2921

Email:peri@econs.umass.edu Website:

hHp://www.umass.edu/peri/

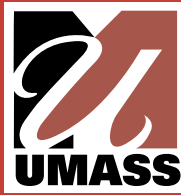




\title{
An Econometric Analysis of International Variations in Child Welfare
}

\author{
Nasrin Dalirazar
}

\section{Introduction}

This paper attempts to further analytical understanding of the ways in which child welfare can be improved. I examine the determinants of international variations in child health, nutrition, and education, analyzing the impacts both of government expenditures and of structural variables, such as income distribution, that are less policy-sensitive in the short run. To control for cross-country variations in child welfare outcomes related to per capita income, I use 'national performance gap' measures of five dimensions of child welfare, and an aggregate index derived from them, as dependent variables.

The paper is organized as follows. Section 2 reviews the literature on the determinants of child welfare. Section 3 provides a brief description of the way in which national performance gaps and the child welfare index are constructed. Section 4 presents a model of the determinants of international variations in child welfare, and discusses the sources of data for the independent variables. Econometric results are presented in Section 5, and Section 6 summarizes the findings and offers some concluding remarks.

\section{Evidence on the Determinants of International Variations in Child Welfare}

Literature from various strands of the social sciences has shed much light on the variables that explain child health, nutrition, education, and cognitive and psychosocial development. The main explanatory variables identified in the literature are family circumstances, accessibility of health care and sanitation, the socioeconomic conditions of the parents at the household level; and the level of income, income distribution, and government expenditures on health and education at the macro level. The literature includes cross-sectional and time-series studies, at both the macro level and the household level, and evaluations of specific public-policy interventions. This section reviews the literature on the following determinants of child welfare: (i) income per capita; (ii) income distribution; (iii) parental and female literacy rates; and (iv) social expenditure and programs for child health and education.

\subsection{Income per Capita}

In a macro study of the Latin America and the Caribbean, Behrman (1996) found that current nursing services, health care at birth, and basic nutrition are important positive factors determining health in Latin America and the Caribbean. The health outcomes were defined as life expectancies at birth, infant and under-five mortality rates, and maternal mortality. Behrman used population per physician, population per nurse, and percentage of births attended by health personnel, and daily calorie supply per capita as the input indicators. All these input indicators increased with increases in per capita 
income. Even after controlling for real per capita income, all the input indicators, with the exception of population per physician, had positive impacts on the health outcomes.

In a time-series study on the long-term trends in Costa Rica from 1910 to 1981, Bixby (1983) provided empirically based evidence on the detrimental effects of world economic recessions on social indicators, including infant mortality. Bixby concluded that progress in health technologies and sanitation do reduce mortality, but that this progress is influenced by the economic cycle, which in turn is influenced by international economic conditions. During economic contractions the infant mortality rate tends to decline at a slower pace, and during economic crises, it rises. These effects take place with a time lag of one to two years.

In cross-sectional studies at the household level, family income has been widely reported to be a key determinant of child welfare ${ }^{1}$. Studies by Mosley (1983) and UNICEF (1981), for example, show a strong positive relationship between household income levels and several child-welfare indicators, including the infant mortality rate, the underfive mortality rate, and child health and nutrition status. Similarly, numerous householdlevel studies have found a significantly positive impact of family income on children's schooling (see, for example, Behrman and Wolfe, 1987a,b; Birdsall, 1985; Farrell, and Schiefelbein, 1985; King and Bellow, 1988). In Brazil, for example, it was estimated that child schooling-attainment increases by 5 to $8 \%$ for a $10 \%$ increase in income.

\subsection{Income Distribution}

Several macro-level studies have shown a relationship between child health, measured by infant mortality rate, and income distribution. Based on a regression model for 47 developing countries, Flegg (1982) concluded that after controlling for other variables, that the reduction in income inequality from the average level to that of the more egalitarian countries would reduce infant mortality by 20 deaths per 1,000 live births. In a study of 282 US metropolitan areas, Lynch et al. (1998) found there were 210.5 excess infant deaths per 100,000 in high-inequality as compared with low-inequality metropolitan areas.

Kawachi et al. (1997) examined the relationship between income inequality and infant mortality in 39 states of the U.S. They estimated that a rise in the share of real income of the rich, defined as the top five percent of the household income distribution, by one percent of national income was associated with a rise in the infant mortality rate of 0.7 to 4.2 percent. Similarly, Waldman (1992) found a significant positive association between income inequality and infant mortality, even after controlling for a number of possible sources for such an association, including doctors per capita, nurses per capita, urbanization indicators, female literacy, and fertility rates.

\footnotetext{
${ }^{1}$ It has been pointed out by Behrman (1996) that family income enters into human resource investment only if: 1) the access to capital market increases with income; 2) due to pressure of poverty, household discount rates are negatively associated with income; or 3) schooling is partly consumption, not just an investment decision.
} 
In a cross-sectional analysis of the 50 U.S. states, Boyce et al. (1999) linked inequalities in the distribution of power (as opposed to income) to variations in infant mortality and public health. They found evidence that this link arises, in part, through adverse impacts of power inequality on the strength of environmental policy and hence on environmental quality. The authors derive an index for power distribution based on voter participation, tax fairness, Medicaid access, and educational attainment. Their econometric results suggest that income distribution is a determinant of power distribution, and hence that the political ramifications of income inequalities have adverse impacts on infant mortality.

Several studies have used time-series analysis to examine the effects of changes in income distribution, on children's health. McCord et al. (1980) traced the rise in death rates in Bangladesh in the mid-1970s by more than 50\% to a sharp decline in real wages. The authors showed that during the period of falling real wages, under-five mortality doubled for the landed families, but it quadrupled for landless agricultural laborers. De Carvalho and Wood (1978) observed that infant mortality rates increased sharply, by 40\% and 68\%, in two major cities in Brazil between 1960 and 1970, and attributed this to the increasingly uneven distribution of income in this period. They also reported that life expectancy at birth for the lower income classes was 12.1 years less than that for the upper-income groups.

\subsection{Female Literacy Rate}

In almost all countries for which data are available, there is a clear and consistent positive relationship between indicators of child welfare and parents' number of years of schooling. For example, studies for Nicaragua, Panama, Brazil, and Peru (Heckman et al. 1986; King et al. 1988; Birdsall 1985; Wolfe and Behrman 1987b) reported significant positive effects of parental schooling on child schooling, with the estimated additional grades of schooling of children for every additional grade of parents ranging from 0.1 to 1.1 .

A particularly important indicator of a family's capacity to protect its children's health has been shown to be the literacy of the mother (see for example, Repetto, 1979). This could be due to the fact that literate women are more likely to be knowledgeable and skilled in health-related matters. Another possible explanation is that to the extent that literacy confers greater status on women, they use their empowerment to advance the interests of the infants and children in the family.

In a study of child mortality in Brazil, Caravel and Burgess (1978) found that the impact of maternal education was as large as that of household income. Caldwell (1979), using Nigerian survey data, found that maternal education was the single most important determinant of child mortality, after controlling for various other family characteristics. Studies by Thomas et al. (1990, 1991, 1992) on child survival, child health, and nutrition status in Brazil showed strong positive effects of parents' schooling, and found that maternal education has a significantly larger effect on child survival than does paternal education. In a similar study for Peru, Behrman and Wolfe (1987a) found that an additional year of mother's schooling increased the life expectancy by 0.33 years for 
female children and 0.29 for male children for the 1925-1939 parental birth cohort; and by 0.12 and 0.18 years, respectively, for the 1960-1966 cohort; the results for an additional year of father's schooling were also positive but smaller in magnitude.

Based on studies in the Philippines and Nicaragua, Wolfe and Behrman (1983; 1987a, 1987b, 1989) also found strong effects of women's schooling in improving child nutrition. Bairagi (1980) obtained similar results in Bangladesh, finding that while increases in family income led to improvement in the nutritional status of children, the nutritional status of children was also constrained by maternal education and maternal income, in the lowest income groups.

\subsection{Social Expenditure}

In an international cross-sectional study, Kakwani (1993) compared the standard of living, measured by three indicators - infant mortality rate, life expectancy at birth, and literacy - across 80 developing countries. The author attributed the success of the highachievers - including Sri Lanka, Israel, Costa Rica, Jamaica, and Barbados - to these countries' investment in public welfare programs, including the direct provision of health, education, and other services.

Public health investments have been found to play a critical role in reducing infant mortality. For example, in a study of the Indian states of Kerala and West Bengal, Nag (1981) reported that greater utilization of medical facilities played a more important role in determining infant and child mortality rate differentials than other factors such as income, income distribution, and urbanization. Behrman (1996), in a comparative study of Latin American and Caribbean countries, reported that, in addition to income per capita, government expenditure on health as a percentage of GDP was a significant determinant of child health and nutrition outcomes.

Other studies have highlighted the importance of public investments in sanitation facilities. In a cross-section study at the household level in the Philippines, for example, Martin et al. (1985) found a correlation between child mortality and the availability of sanitation and electricity, controlling for other variables. Guerra (1981) showed that clean water supply and sewage disposal were as important as maternal characteristics in determining infant mortality. In studies in Sri Lanka and in Mexico, Hobcraft et al. (1982) found a relationship between access to toilet facilities and child mortality.

Evidence on the positive impacts of child health and education programs from intervention evaluations abounds. These, too, suggest the importance of social expenditure. Here I will cite several such studies to illustrate. ${ }^{2}$ Various studies have examined the effects of food supplementation interventions in developing countries. Analyzing the effects of a Jamaican program on child growth, Grantham-McGregor and others (1991) concluded that nutritional supplementation improved growth after 1 year of intervention. Super et al. (1990) found that at 3 years of age children who had received

\footnotetext{
${ }^{2}$ For more comprehensive reviews, see Myers (1995) and Young (1995).
} 
nutritional supplements were 2.6 centimeters taller and 642 grams heavier than the control group. Supplemental feeding has also been found to result in improved scores on tests of knowledge, numeracy, reading, and vocabulary. Chavez et al. (1995), in a study in Mexico spanning 24 years, concluded that nutritional supplementation to pregnant and lactating women and children improved infant behavior, child IQ, behavior at school, school performance, and adult body size. A study of children in West Java, Indonesia, found that children 18 months old or younger who received supplements performed better on both motor and mental development (Pollitt and Oh 1994), and on tests on memory eight years later (Pollitt et al. forthcoming).

Various studies have examined the effects of emotional stimulation combined with supplementation interventions. For example, in an intervention program in Jamaica, households with malnourished children aged 9-24 months were provided a supplement of milk-based formula and stimulation consisting of play-time activities. Children who received both supplementation and stimulation had higher levels of DQs (Development Quotient). Cohorts receiving stimulation improved in all of the subscales, but those receiving supplements showed much greater improvements in the locomotor subscale (Grantham-McGregor and others 1991).

Studies have also reported positive changes as a result of parental 'education-and-support programs'. In the Turkish Early Enrichment Project, for example, the children in the experimental group outperformed the control group in school achievement, socioemotional development, and emotional health (Kagitcibasi et al. 1988; Kagitcibasi, 1991, $1993,1996)^{3}$.

\subsection{Violent Conflict}

Both conventional wars and "low intensity" wars often disrupt medical, social, educational and public services, all of which can have severe impacts on child welfare. The direct effects of war on children via the mortality and morbidity associated with armed conflict are magnified by the indirect effects that occur as a result of disruption of food supplies, health care and education and the displacement of families. In a study of the impact of Mozambique's 1981-1988 civil war on children, Cliff and Noormahomed (1993) found that civil strife resulted in closure of $48 \%$ of the country's primary health care facilities and $45 \%$ of primary schools, and that the war led to an estimated 494,000 excess childhood deaths, and an estimated 200,000 children separated from their families or orphaned. To cite another example, during the 1991 Gulf war, the collapse of Baghdad's water system in Baghdad resulted in a marked increase in the incidence of water-borne diseases such as cholera, typhoid, and gastroenteritis, particularly among children (Goldson, 1996).

\footnotetext{
${ }^{3}$ Studies in the U.S. have also reported positive changes in parental behavior as a result of such programs , including increased knowledge of child development (Rodriguez, 1983; Rodriguez et al. 1988); increased recognition of their role as teachers (Travers et al. 1982; Slaughter, 1983); better care-giving, through a better sense of control and improved communication; improved maternal knowledge; and more involvement with teachers (Andrews et al. 1982; Gray et al. 1980; Slaughter, 1983; Hauser-Cram, 1983).
} 
The Graca Machel Study (1996), commissioned by the UN, provided the first comprehensive assessment of the impact of armed conflict on children. The Machel Study's major finding was that children are impacted by war in eight key areas: 1) the use of children as soldiers; 2) displacement; 3) sexual exploitation; 4) landmines; 5) sanctions; 6) health and nutrition; 7) psychosocial effects; and 8) education. Each of these has a profound effect on children's lives, and children caught in wars experience multiple chronic stresses that increase exponentially with the duration, severity, and frequency of conflict (Garbarino and Kostelny, 1996).

An updated version of the Machel Study (2000) found that the psychosocial impacts of armed conflict on children are displayed in various symptoms ranging from separation anxiety, developmental delays, sleep disturbances, nightmares, and decreased appetite, to withdrawn behavior, a lack of interest in play in younger children, and aggressive behavior and depression in older children. In Sarajevo, where almost one in every four children was wounded in conflict during the Bosnian war, UNICEF found that $97 \%$ of the children had experienced shelling, 29\% felt "unbearable sorrow," $20 \%$ had terrifying dreams; some $55 \%$ had been shot at by snipers; and $66 \%$ experienced a situation in which they thought they would die (UNICEF, 1993). Similarly, in a study in Angola, UNICEF reported that $66 \%$ of children had witnessed murders, , $67 \%$ had witnessed war atrocities; and $91 \%$ had seen dead people (UNICEF, 1993).

Drawing on 24 country case studies, the 1996 Machel study along with Brett, McCallin and O'Shea (1996) estimated that at the time there were approximately 250,000 child soldiers, including many under the age of 15 years. In Uganda in 1986, for example, there were an estimated 3000 children as combatants, including 500 girls (Brett, McCallin, and O'Shea 1996). In Myanmar in 1990, an estimated 900 of the 5000-strong Karen army were children under the age of 15 (Dodge 1991). Girls abducted into armed groups are often coerced into sexual slavery, and many become infected with sexually transmitted diseases and increasingly with HIV/AIDS (Hick, 2001).

The 2000 Machel Study (2000) estimated that one in every 300 children on earth is displaced by armed conflict, and that there are about 40 million refugees and displaced persons worldwide, most of whom are women and children. Children as refugees often lose their chances of receiving education, proper nutrition, and health care. In Colombia, some $85 \%$ of refugee children do not receive primary education (Hick, 2001). Many child refugees die within the first days and weeks of displacement due to malnutrition and diseases. Unaccompanied minors - that is, children who are orphaned, lost, or typically separated in the panic of flight - typically account for $5 \%$ of refugee population (Ressler, Tortocici, and Marcelino, 1993). In some cases, the numbers are higher. In Angola in 1995 , for example, $20 \%$ of country's children were estimated to be separated from their parents (Hick, 2001). Clearly, then, any study of the determinants of international variations in child welfare in the contemporary world must take into account the impacts of violent conflict. 


\section{Child Welfare Indicators}

Child welfare indicators have been traditionally classified into three broad categories: nutrition, health, and education ${ }^{4}$. In this paper, child welfare is defined in terms of all three areas. Specifically, I use data on: (1) the infant mortality rate (IM); (2) the under-five mortality rate (U5M); (3) the under-five rate of malnutrition (STUNT); (4) the primary school enrollment ratio (PEN); and (5) the percentage of children reaching grade 5 (TRG5). For each of these variables, I calculate "national performance gaps" using the methodology described below. In addition, I derive a composite measure of child welfare, WINOCENT, as the indicator of the overall welfare of children. These child-welfare measures, calculated for all low-income and middle-income countries for which the necessary raw data are available, are used as dependent variables in the analysis of the determinants of international variations in child welfare.

\subsection{Data Sources}

I restrict my analysis to countries with a per capita real income of fifteen thousand dollars or less, using purchasing power parity-adjusted gross national product per capita (GNPPC), averaged over the years 1996-98, as the real-income variable (calculated from data reported by the World Bank's World Development Indicators) ${ }^{5}$.

IM (the infant mortality rate) is defined as the number of children who die between birth and one year of age, per 1000 live births. Data on this variable are taken from the World Health Organization's World Health Report 1999. Most of these data refer to the years 1995 to 1998; in cases where data for these years are not available, I use data from as far back as 1992 .

U5M (the under-five mortality rate) is the number of children who die between birth and five years of age, per 1000 live births. Data on U5M are also taken from WHO's World Health Report 1999. Again, in cases where data from 1995-1998 were unavailable, I use data from as far back as 1992.

STUNT refers to the percentage of children under five years of age who are moderately to severely malnourished ${ }^{6}$. The primary sources of data for this variable are the World

\footnotetext{
${ }^{4} \mathrm{~A}$ fourth indicator, increasingly discussed in literature as a separate category, is cognitive and behavioral development (see Pollitt and Gorman, 1989). Owing to the lack of internationally comparable data on this dimension, it is not included here.

${ }^{5}$ High-income countries are excluded on the grounds that child-welfare variations among them may arise from a different set of determinants (including, for example, substance abuse and the prevalence of firearms).

${ }^{6}$ According to the World Health Organization (2000b), stunted growth reflects a process of failure to reach linear growth potential as a result of sub-optimal health and/or nutritional conditions. The degree of stunting is measured by the height-for-age ratio criterion: the World Health Organization defines moderate stunting as being two standard deviations or more below the median value of height-for-age.
} 
Health Organization's World Health Report 1999 and Global Database on Child Growth and Malnutrition $2000^{7}$.

PEN (the net primary enrollment rate) refers to the total enrollment in primary education in the age group corresponding to the official school age for primary education, divided by the population of the same age group ${ }^{8}$. Data on PEN are taken from UNESCO's World Education Report 2000 for the years 1995-1998; again, when data were not available for those years, I used data from as far back as 1992. The raw data on education indicators appear to be of relatively poor quality, compared to the data on health and nutrition ${ }^{9}$.

TRG5 (the percentage of children completing five years of schooling) is calculated from data on the percentage of primary school entrants who reach grade five (RG5). The primary source of these data is the World Bank's World Development Indicators, $2000^{10}$. Although RG5 is a useful indicator of school performance, for the purposes of the present analysis, I instead calculate the total percentage of all children in the relevant age group who reach grade five (TRG5) ${ }^{11}$.

\footnotetext{
${ }^{7}$ Further data are available from UNICEF's State of the World's Children 2000. There are systematic discrepancies, however, between the WHO and UNICEF data. For countries for which data from both the WHO and UNICEF are available, the average ratio of the WHO data to UNICEF data was 1.6. Therefore, for the fairly small number of countries for which the WHO does not report data but UNICEF does, I used the UNICEF figures, scaling them upwards by a factor of 1.6.
}

${ }^{8}$ The gross primary enrollment rate refers to the total enrollment in primary education, regardless of age, divided by the population of the age group which officially corresponds to primary schooling. I also examined data on this variable, but I do not report it here as the data on net PEN appear to be more consistent.

${ }^{9}$ It is doubtful, for example, whether the $100 \%$ enrollment rate reported for Cambodia is accurate. In some cases, the education data may be a better indicator of administrative norms than of on-the- ground realities. It is noteworthy that the WHO's World Health Report presents health data in tables distinguished according to their degree of reliability. In contrast, UNESCO's World Education Report does not offer any indications as to the degree of reliability of the national data.

${ }^{10}$ In cases where data were unavailable from the World Bank, data were taken from UNICEF's State of the World's Children 2000 and from UNESCO's World Education Report 2000. For countries where data are available from both the World Bank and the United Nations sources, the average ratio of the former to the latter was 0.99 . Therefore, data on this variable from the UNICEF and UNESCO were assimilated with the data from the World Bank without any adjustment.

11 To calculate TRG5, I used data for two variables: the percentage of primary school entrants who reach grade five (RG5) and the net primary enrollment rate (PEN). Let TRG1 $=$ the percentage of all children who enroll in grade one:

(RG5)(TRG1) = TRG5

Assuming a linear school drop-out rate between grades one and five, PEN (for all five years) can be expressed as the simple average of TRG1 and TRG5:

PEN $=($ TRG1 + TRG5) $/ 2$

Substituting terms:

PEN = (TRG5 / RG5 + TRG5) / 2

Simplifying and rearranging terms, we get:

TRG5 $=2(\mathrm{PEN}) /(1+1 / \mathrm{RG} 5)$ 


\subsection{Calculation of the National Performance Gaps}

Building on the pioneering work of UNICEF (1995), I calculate National Performance Gaps (NPGs) ${ }^{12}$ for the five child-welfare indicators - the infant mortality rate; the underfive mortality rate; under-five malnutrition; the primary-school enrollment rate; and the percentage of children reaching grade five - for 112 lower and middle-income countries.

The first step in the calculation of the NPGs is the estimation of the relationship between each of these child-welfare measures and real income per capita, using ordinary least squares (OLS) regression analysis (for details, see Dalirazar, 2002) ${ }^{13}$. I then derived the expected values for each of the five child-welfare variables. These expected values were subtracted from the actual values of the child-welfare variables to yield the gap between actual outcomes and the performance that would be expected on the basis of income alone. A positive gap thus indicates that actual values are higher than expected; a negative value indicates the reverse. Finally, this gap was divided by the expected value to obtain the NPG, here defined as the percentage by which actual outcomes diverge from the outcomes expected on the basis of per capita income. For the health and nutrition variables (IM, U5M, and STUNT) positive NPGs reflect worse performance than that expected, whereas for the education variables (PEN and TRGs) positive values indicate better-than-expected performance. Table 1 presents NPGs for the five child-welfare variables.

\subsection{WINOCENT: An International Index of Child Welfare}

Children's well-being has multiple dimensions encompassing health, nutrition, and education. The composite of these dimensions, and the interactions among them, ultimately define children's status. To obtain a holistic indicator of child welfare, that provides a fuller picture of their situation than any single dimension, I derive a "Welfare Index of Children in their Entirety," or WINOCENT for short. The WINOCENT index is the simple average of the NPGs for five child-welfare indicators discussed above. The signs of the NPGs for the health and nutrition variables were reversed, so that a higher value of WINOCENT denotes greater child welfare ${ }^{14}$.

\footnotetext{
12 The concept of National Performance Gap was first introduced by the UNICEF in the publication The Progress of Nations, in 1993, and updated in the 1995 and 1996 editions. This represented the first attempt to assemble an international set of child-welfare indicators that would allow comparisons across countries and over time, controlling for differences in national income per capita.

${ }^{13}$ The double-log specification (which implies a constant elasticity of child welfare with respect to income) yields the highest adjusted $\mathrm{R}^{2}$ for all the five indicators on average.

${ }^{14}$ Like other social and economic indexes, such as the United Nations Development Programme's HDI (Human Development Index) and GEM (Gender Equality Measure), WINOCENT provides a convenient measure of a multi-dimensional phenomenon, in this case children's welfare. It thereby provides a tool for gauging the extent to which the needs of children as a whole are met.
} 
Table 1 Child Welfare Indicators

\begin{tabular}{|c|c|c|c|c|c|c|}
\hline \multirow[t]{2}{*}{ Country } & \multicolumn{3}{|c|}{ Health Variables } & \multicolumn{2}{|c|}{ Education Variables } & \multirow{2}{*}{$\begin{array}{l}\text { WINOCENT } \\
\text { Index }\end{array}$} \\
\hline & $\mathbf{N P G}_{\mathrm{IM}}$ & $\mathbf{N P G}_{\mathrm{U} 5 \mathrm{M}}$ & $\mathbf{N P G}_{\text {STUNT }}$ & $\mathbf{N P G}_{\text {PEN }}$ & $\mathbf{N P G}_{\text {TRG5 }}$ & \\
\hline Albania & -13 & -42 & -32 & 28 & 39 & 31 \\
\hline Algeria & 0 & 30 & 20 & 11 & 19 & -8 \\
\hline Angola & -7 & 60 & 27 & -40 & -57 & -36 \\
\hline Argentina & -10 & 47 & -45 & 0 & ... & .. \\
\hline Armenia & 5 & -69 & -50 & .. & .. & .. \\
\hline Azerbaijan & -21 & -72 & -22 & .. & .. & .. \\
\hline Bangladesh & -18 & -10 & 53 & 23 & 7 & 1 \\
\hline Belarus & -20 & -49 & .. & -6 & 2 & .. \\
\hline Benin & 23 & 27 & -35 & 14 & 19 & 4 \\
\hline Bolivia & 17 & 53 & 32 & 30 & 16 & -12 \\
\hline Botswana & 19 & 400 & 142 & -19 & -20 & -120 \\
\hline Brazil & 0 & 74 & -17 & 2 & -12 & -14 \\
\hline Bulgaria & -9 & -55 &.. & 14 & 23 & ... \\
\hline Burkina Faso & 5 & 62 & -22 & -44 & -32 & -25 \\
\hline Burundi & 1 & -2 & -9 & -30 & -9 & -6 \\
\hline Cambodia & -2 & 45 & 43 & 62 & 41 & 4 \\
\hline Cameroon & 11 & 93 & -11 & -8 & -4 & -21 \\
\hline Central African Rep. & 12 & 66 & -18 & -26 & -62 & -30 \\
\hline Chad & 2 & 27 & -7 & -16 & -10 & -10 \\
\hline Chile & 19 & -15 & -78 & -10 & -10 & 11 \\
\hline China & 0 & -17 & 64 & 27 & 43 & 5 \\
\hline Colombia & 6 & 22 & 25 & -8 & -18 & -16 \\
\hline Congo Dem. Rep. & 0 & -11 & -7 & 8 & 11 & 8 \\
\hline Congo Rep. & 31 & 37 & -42 & 28 & 29 & 7 \\
\hline Costa Rica & 0 & -35 & -50 & -7 & -8 & 14 \\
\hline Côte d'Ivoire & 4 & 79 & -20 & -13 & -2 & -16 \\
\hline Croatia & -20 & -63 & -93 & 10 & 17 & 41 \\
\hline Czech Republic & -10 & -58 & -78 & 0 & -1 & 25 \\
\hline Dominican Rep. & 0 & 54 & -27 & 5 & -16 & -8 \\
\hline Ecuador & 32 & 13 & 113 & 18 & 22 & -24 \\
\hline Egypt Arab Rep. & -7 & 35 & 25 & 22 & 42 & 3 \\
\hline El Salvador & -20 & -15 & 22 & 12 & 14 & 8 \\
\hline Eritrea & -2 & -26 & -5 & -51 & -43 & -13 \\
\hline Estonia & -22 & -52 & .. & 8 & 13 & .. \\
\hline
\end{tabular}


Table 1 Child Welfare Indicators (Cont'd)

\begin{tabular}{|c|c|c|c|c|c|c|}
\hline \multirow{2}{*}{ Country } & \multicolumn{3}{|c|}{ Health Variables } & \multicolumn{2}{|c|}{ Education Variables } & \multirow{2}{*}{$\begin{array}{c}\text { WINOCENT } \\
\text { Index }\end{array}$} \\
\hline & $\mathbf{N P G}_{\mathbf{I M}}$ & $\mathbf{N P G}_{\mathbf{U} \mathbf{M}}$ & NPG $_{\text {STUNT }}$ & NPG $_{\text {PEN }}$ & $\mathbf{N P G}_{\text {TRG5 }}$ & \\
\hline Ethiopia & -11 & -23 & 5 & -29 & -25 & -5 \\
\hline Gabon & 6 & 474 & .. & .. & .. & .. \\
\hline Gambia & -7 & -13 & -10 & 4 & 25 & 12 \\
\hline Georgia & -28 & -64 & -48 & 21 & 46 & 42 \\
\hline Ghana & -4 & 28 & -8 & .. & .. & .. \\
\hline Greece & 0 & -34 & .. & 0 & 0 & .. \\
\hline Guatemala & 8 & 45 & 195 & -11 & -33 & -59 \\
\hline Guinea & -2 & 149 & 4 & -33 & -23 & -42 \\
\hline Guinea Bissau & 30 & 37 & -20 & -6 & -54 & -22 \\
\hline Haiti & -10 & 18 & -9 & -68 & -72 & -28 \\
\hline Honduras & -7 & -21 & 67 & 23 & 12 & -1 \\
\hline Hungary & -20 & -37 & -73 & -2 & -2 & 26 \\
\hline India & -16 & 14 & 86 & 14 & 8 & -13 \\
\hline Indonesia & 19 & 19 & 110 & 27 & 39 & -17 \\
\hline Iran Islamic Rep. & 5 & 27 & 36 & -2 & 2 & -14 \\
\hline Jamaica & 0 & -40 & -62 & 19 & 36 & 32 \\
\hline Jordan & 16 & -28 & -16 & -14 & 0 & 3 \\
\hline Kazakhstan & -15 & -22 & -6 &.. & .. & .. \\
\hline Kenya & 8 & 9 & -11 & 9 & 21 & 5 \\
\hline Korea Rep. & 0 & -9 &.. & 0 & 0 & .. \\
\hline Kyrgyzstan & -7 & -33 & 0 & 41 & 71 & 31 \\
\hline Lao PDR & -17 & 47 & 47 & 15 & 9 & -11 \\
\hline Latvia & -21 & -39 &.. & 15 & 26 & .. \\
\hline Lebanon & 25 & 16 & -15 & -18 & .. & .. \\
\hline Lesotho & 5 & 158 & 92 & -6 & 4 & -52 \\
\hline
\end{tabular}


Table 1 Child Welfare Indicators (Cont'd)

\begin{tabular}{|c|c|c|c|c|c|c|}
\hline \multirow[t]{2}{*}{ Country } & \multicolumn{3}{|c|}{ Health Variables } & \multicolumn{2}{|c|}{ Education Variables } & \multirow{2}{*}{$\begin{array}{l}\text { WINOCENT } \\
\text { Index }\end{array}$} \\
\hline & $\mathbf{N P G}_{\mathrm{IM}}$ & $\mathbf{N P G}_{\text {U5M }}$ & NPG $_{\text {STUNT }}$ & $\mathbf{N P G}_{\mathrm{PEN}}$ & NPG $_{\text {TRG5 }}$ & \\
\hline$\underline{\text { Lithuania }}$ & -23 & -59 &.. &.. &.. &.. \\
\hline Macedonia & -15 & -52 &.. & 15 & 28 & .. \\
\hline Madagascar & 9 & 3 & 12 & 9 & -8 & -5 \\
\hline Malawi & 11 & 26 & -10 & 91 & 46 & 22 \\
\hline Malaysia & 16 & -30 & 200 & 0 & 0 & -38 \\
\hline Mali & -1 & 29 & -42 & -29 & -3 & -4 \\
\hline Mauritania & 6 & 82 & 38 & -15 & -14 & -31 \\
\hline Mauritius & 8 & 30 & 0 & -3 & -3 & -9 \\
\hline Mexico & 0 & 85 & 110 & 0 & -7 & -41 \\
\hline Moldova & -20 & -72 & .. & .. &.. & .. \\
\hline Mongolia & 6 & -25 & -17 & 29 & 59 & 25 \\
\hline Morocco & 0 & 46 & 27 & -8 & -5 & -18 \\
\hline Mozambique & -15 & 17 & -34 & -24 & -26 & -4 \\
\hline Namibia & 0 & 315 & 108 & 0 & -4 & -86 \\
\hline Nepal & -8 & -3 & 30 & 30 & 23 & 7 \\
\hline Nicaragua & -6 & -41 & -12 & 17 & 6 & 17 \\
\hline Niger & 8 & 72 & -16 & -57 & -47 & -34 \\
\hline Nigeria & 6 & -19 & -7 & 8 & .. & .. \\
\hline$\underline{\text { Pakistan }}$ & -4 & 52 & 104 &.. &.. & .. \\
\hline$\underline{\text { Panama }}$ & 17 & 9 & -25 & -6 & -10 & -4 \\
\hline Papua New Guinea & 11 & 44 & 96 & 6 & -5 & -30 \\
\hline$\underline{\text { Paraguay }}$ & -12 & -23 & -18 & 15 & 15 & 17 \\
\hline Peru & 5 & 47 & 63 & 9 &.. & .. \\
\hline Philippines & -4 & 6 & 84 & 22 & 16 & -10 \\
\hline Poland & -12 & -50 &.. & 3 & 6 &.. \\
\hline$\underline{\text { Portugal }}$ & 0 & -28 &.. & 0 &.. &.. \\
\hline Romania & -14 & -14 & -47 & 13 & 21 & 22 \\
\hline$\underline{\text { Russian Federation }}$ & -19 & -32 & -14 & 13 &.. & .. \\
\hline$\underline{\text { Saudi Arabia }}$ & -9 & 74 & & -40 & -43 & .. \\
\hline Senegal & 12 & 48 & -24 & -10 & 10 & -8 \\
\hline
\end{tabular}


Table 1 Child Welfare Indicators (Cont'd)

\begin{tabular}{|c|c|c|c|c|c|c|}
\hline \multirow[t]{2}{*}{ Country } & \multicolumn{3}{|c|}{ Health Variables } & \multicolumn{2}{|c|}{ Education Variables } & \multirow{2}{*}{$\begin{array}{l}\text { WINOCENT } \\
\text { Index }\end{array}$} \\
\hline & $\mathbf{N P G}_{\mathbf{I M}}$ & $\mathbf{N P G}_{\mathbf{U} \mathbf{M}}$ & NPG $_{\text {STUNT }}$ & NPG $_{\text {PEN }}$ & NPG $_{\text {TRG5 }}$ & \\
\hline Sierra Leone & -3 & 13 & -48 & -7 & .. & .. \\
\hline Slovak Republic & -15 & -45 & .. & .. & .. & .. \\
\hline Slovenia & -10 & -42 & .. & -5 & -5 &.. \\
\hline South Africa & -7 & 337 & 110 & 0 & -13 & -91 \\
\hline$\underline{\text { Sri Lanka }}$ & -14 & -66 & 10 & 34 & 45 & 30 \\
\hline$\underline{\text { Sudan }}$ & 2 & 10 & 0 & .. & .. & .. \\
\hline Syrian Arab Rep. & 6 & -31 & 5 & 22 & 41 & 17 \\
\hline Tajikistan & -5 & -73 & 0 & 58 &.. &.. \\
\hline Tanzania & 8 & -36 & -28 & -4 & 31 & 17 \\
\hline Thailand & 6 & 44 & 24 & -8 & -9 & -19 \\
\hline Togo & 5 & 70 & 10 & 27 & 36 & -5 \\
\hline Trinidad \& Tobago & -12 & -19 & -59 & 5 & 7 & 21 \\
\hline Tunisia & -10 & 11 & 47 & 13 & 18 & -4 \\
\hline Turkey & 0 & 83 & 67 & 5 & 8 & -28 \\
\hline Uganda & -2 & 51 & 0 & .. & -5 & .. \\
\hline Ukraine & -21 & -68 & .. & .. & .. & .. \\
\hline Uruguay & -8 & 6 & -10 & -6 & -6 & 0 \\
\hline Uzbekistan & 5 & -50 & 30 & .. &.. & .. \\
\hline Venezuela & 27 & 25 & 19 & -17 & -20 & -22 \\
\hline Vietnam & -6 & -47 & 57 & 52 & .. & .. \\
\hline Yemen Rep. & 6 & -42 & 2 & .. & .. & .. \\
\hline Zambia & 14 & 30 & -9 & 31 & 70 & 14 \\
\hline Zimbabwe & -10 & 120 & -9 & 28 & 39 & -7 \\
\hline
\end{tabular}


Thus: WINOCENT $=\left(-\mathrm{NPG}_{\mathrm{IM}_{\mathrm{M}}}-\mathrm{NPG}_{\mathrm{U} 5 \mathrm{M}}-\mathrm{NPG}_{\mathrm{STUNT}}+\mathrm{NPG}_{\mathrm{PEN}}+\mathrm{NPG}_{\mathrm{TRG}} \tilde{)}\right) 5$

The final column of Table 1 presents the WINOCENT index. The best performer is Georgia, with a WINOCENT of 42; that is, child welfare in Georgia is, on average, $42 \%$ higher than would be expected on the basis of its national income. The worst performer is Botswana, with a WINOCENT of minus 120; that is, child welfare is less than half of what would be expected on the basis of national income.

\section{An Econometric Model of Determinants of Child Welfare}

Drawing on the literature reviewed in Section 2, I identify five variables to test for their salience in determining international variations in child welfare. These fall into two broad categories, structural variables and policy variables. The structural variables are the Gini coefficient of income inequality; the presence of civil strife and conflict; and the female literacy rate. The policy variables are public expenditures on health and education. The dependent variables are the WINOCENT index and the five national performance gaps from which it is derived. The distinction between structural and policy rests on the relative ease with which they can be altered in the short term through policy interventions. The level of government expenditures can be fairly readily altered by policy makers. The structural variables are less amenable to short-run manipulation. However, the distinction between the two is not hard and fast. Over the medium-to-long term, structural variables such as income distribution and literacy can be altered by policy choices; indeed, such structural changes are, in a sense, synonymous with development. At the same time, the fiscal policy variables can reflect underlying structural opportunities and constraints. While not absolute, the distinction nevertheless is useful for analytical purposes, helping to clarify the extent to which short-run policies and longer-run structural changes affects child welfare.

\subsection{The Model}

The regression model has the following general form:

$\underline{\mathrm{CW}}=\alpha+\beta_{1} \underline{\mathrm{GINI}}+\beta_{2} \underline{\mathrm{GINI}} * \underline{\mathrm{YPC}}+\beta_{3} \underline{\mathrm{EXP}}+\beta_{4} \underline{\mathrm{FLIT}}+\beta_{5} \underline{\mathrm{CONFLICT}}+\mathrm{u}$

where $\underline{\mathrm{CW}}$ measure is the child-welfare indicator; GINI is the Gini coefficient of income distribution (a higher value of which denotes greater inequality), YPC is income per capita, here interacted with income distribution to allow for the possibility that the impact of the latter is conditioned by the level of per capita income; EXP is public expenditure as percentage of GDP; FLIT is the female literacy rate, CONFLICT is a measure of the degree of civil strife and discontent; and $u$ is an error term with the usual properties. Regressions are estimated using the ordinary least squares method.

In the regressions for health and nutrition (where $\mathrm{CW}$ is variously defined as $\mathrm{NPG}_{\mathrm{IM}}$, $\mathrm{NPG}_{\mathrm{U} 5 \mathrm{M}}$, and $\mathrm{NPG}_{\mathrm{STUNT}}$ ), EXP refers to public health expenditure. In the regressions for education (where $\mathrm{CW}$ is taken as $\mathrm{NPG}_{\mathrm{PEN}}$, or $\mathrm{NPG}_{\mathrm{TRG}}$ ), $\mathrm{EXP}$ refers to public education 
expenditure. In the regression for the aggregate child-welfare index (where $\mathrm{CW}$ takes the value of WINOCENT), EXP is the sum of public expenditure on health and public expenditure on education.

\subsection{Independent Variables}

The sources of data for the independent variables are as follows: The Gini coefficient (as well as) income per capita, is taken from the World Bank's World Development Indicators 2000 (World Bank 2000). The 'conflict' variable is from a World Bank data on 'armed conflict' (Kaufmann et al. 1999) ${ }^{15}$. The variable is scaled from -2 to +2 , such that a higher number denotes a higher degree of instability and violence. The female literacy rate, defined as the percentage of women 15 years or older who can read and write, is included not only because of the potential impact of a mother's literacy on her children's health and education, but also because higher literacy rates may be associated with a more equal distribution of power in society (see, for example, Torras and Boyce 1998), and because higher female literacy, in particular, is likely to be associated with greater gender equality. The data are from UNESCO's World Education Report 2000 (UNESCO, 2000).

Public health expenditure, measured as a percentage of national income, refers to "recurrent and capital spending from government (central and local) budgets, external borrowings and grants (including donations from international agencies and nongovernmental organizations), and social (or compulsory) health insurance funds" (World Bank, 2000, p. 93). The data are from the World Health Organization's World Health

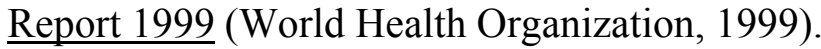

Public education expenditure, which includes spending on public education at the primary, secondary, and tertiary levels, is from UNESCO's World Education Report $\underline{2000}$ (UNESCO, 2000) $^{16}$. For the analysis of the determinants of variations in the aggregate child welfare variable, WINOCENT, social expenditure (the sum of health and education expenditures) was obtained after converting the data on health expenditure as a percentage of GDP were converted into health expenditure as a percentage of GNP, using the GNP/GDP ratio as a scalar. Descriptive statistics for each of the variables used in the analysis are presented in Table 2.

\footnotetext{
15 The data were retrieved from the following website: http://www.worldbank.org/wbi/governance/gov_data.htm

16 These are reported as a percentage of GNP (rather than GDP, as in the case of the health variables), a difference that is unlikely to affect the regression results substantially.
} 
Table 2 Descriptive Statistics

\begin{tabular}{|c|c|c|c|c|}
\hline Variable & Mean & Maximum & Minimum & $\mathbf{N}$ \\
\hline \multicolumn{5}{|l|}{ Independent Variable } \\
\hline Gini & 41.52 & 62.9 & 19.5 & 86 \\
\hline Gini-Income & 158,957 & 611,104 & 19,680 & 86 \\
\hline \multicolumn{5}{|l|}{ Interaction } \\
\hline CONFLICT & 0.27 & 2.59 & -1.39 & 105 \\
\hline Public Health & 2.74 & 7.59 & 0.04 & 112 \\
\hline \multicolumn{5}{|l|}{ Expenditure } \\
\hline Education & 4.51 & 10.6 & 1.4 & 93 \\
\hline \multicolumn{5}{|l|}{ Expenditure } \\
\hline FLIT & 67.06 & 99.8 & 7.1 & 94 \\
\hline Social Expenditure & 10.02 & 18.5 & 4.3 & 93 \\
\hline \multicolumn{5}{|l|}{ Dependent Variable } \\
\hline $\mathrm{NPG}_{\mathrm{IM}}$ & -1.14 & -28 & 32 & 112 \\
\hline $\mathrm{NPG}_{\mathrm{U} 5 \mathrm{M}}$ & 19 & -73 & 474 & 112 \\
\hline $\mathrm{NPG}_{\mathrm{STUNT}}$ & 11,31 & -93 & 200 & 96 \\
\hline $\mathrm{NPG}_{\mathrm{PEN}}$ & 3.66 & -68 & 91 & 98 \\
\hline $\mathrm{NPG}_{\mathrm{TRG} 5}$ & 4.83 & -72 & 71 & 90 \\
\hline WINOCENT & -7.58 & -120 & 42 & 79 \\
\hline
\end{tabular}

\section{Regression Results: Determinants of Child Welfare}

\subsection{Health}

The regression results for the determinants of national performance gaps in the three child health variables - infant mortality, under-five mortality, and stunting - are reported in Table 6. In each case, two specifications are reported: first, the complete model, including all independent variables; and second, a more parsimonious model obtained via a stepwise procedure in which those variables with the least significant estimated coefficients are dropped one-by-one, until the final model retains only those variables whose coefficients are statistically significant at the 10 percent level. Recall that in the case of the child health performance gaps, a higher value of the dependent variable denotes worse performance (higher infant mortality, etc.) than expected on the basis of the country's per capita income. 
Table 3 Determinants of Health Performance Gaps

\begin{tabular}{|c|c|c|c|c|c|c|}
\hline \multirow{2}{*}{$\underbrace{\text { Dependent }}_{\begin{array}{c}\text { Independent } \\
\text { Variable }\end{array}}$ Variable } & \multicolumn{2}{|c|}{$\mathrm{NPG}_{\mathrm{IM}}$} & \multicolumn{2}{|c|}{$\mathrm{NPG}_{\mathrm{USM}}$} & \multicolumn{2}{|c|}{ NPG $_{\text {STUNT }}$} \\
\hline & (1) & (2) & (1) & (2) & (1) & (2) \\
\hline Gini & $\begin{array}{l}0.31^{*} \\
(1.85)\end{array}$ & $\begin{array}{c}0.54^{* * * *} \\
(4.36)\end{array}$ & $\begin{array}{l}1.73 * * \\
(2.26)\end{array}$ & $\begin{array}{c}1.79 * * \\
(2.35)\end{array}$ & $\begin{array}{c}0.75 \\
(0.78)\end{array}$ & - \\
\hline Gini-Income Interaction & $\begin{array}{c}2.17 \mathrm{E}-05^{*} \\
(1.58)\end{array}$ & - & $\begin{array}{c}1.40 \mathrm{E}-04 * * \\
(2.21)\end{array}$ & $\begin{array}{c}1.40 \mathrm{E}-04^{* *} \\
(2.17)\end{array}$ & $\begin{array}{c}9.47 \mathrm{E}-05 \\
(1.17)\end{array}$ & $\begin{array}{c}-3.45 \mathrm{E}-05^{* *} \\
(-2.57)\end{array}$ \\
\hline Female Literacy & $\begin{array}{c}-0.06 \\
(-0.87)\end{array}$ & - & $\begin{array}{c}-0.6^{*} \\
(-1.92)\end{array}$ & $\begin{array}{c}-0.67 * * \\
(-2.28)\end{array}$ & $\begin{array}{c}0.3 \\
(0.79)\end{array}$ & $\begin{array}{c}-0.13^{* *} \\
(-2.10)\end{array}$ \\
\hline CONFLICT & $\begin{array}{c}2.30 \\
(1.00)\end{array}$ & - & $\begin{array}{c}18.9 * * \\
(1.78)\end{array}$ & $\begin{array}{c}20.0 * * \\
(1.91)\end{array}$ & $\begin{array}{c}7.00 \\
(0.60)\end{array}$ & - \\
\hline Public-Health Expenditure & $\begin{array}{l}-1.03 \\
(-1.00)\end{array}$ & - & $\begin{array}{l}-3.43 \\
(-0.72)\end{array}$ & - & $\begin{array}{c}-22.16^{* * *} \\
(-3.76)\end{array}$ & $\begin{array}{l}-4.0^{* * * *} \\
(-3.53)\end{array}$ \\
\hline $\mathrm{R}^{2}$ & 0.13 & 0.17 & 0.27 & 0.28 & 0.18 & 0.48 \\
\hline $\mathrm{N}$ & 86 & 86 & 72 & 72 & 59 & 66 \\
\hline
\end{tabular}

Notes:

A positive value of $\mathrm{NPG}_{\mathrm{IM}}$ denotes higher-than-expected infant mortality rate.

$* * *=$ Significant at $1 \%$

level

$* *=$ Significant at $5 \%$

level

* = Significant at $10 \%$

level 


\subsubsection{Infant Mortality Rate}

The regression results for the NPG in the infant mortality rate are reported in the first two columns of Table 3. In both specifications, the estimated coefficient on the Gini index of income inequality is statistically significant. Greater income inequality was thus associated with a higher gap between actual and expected infant mortality. The positive coefficient on Gini-income interaction term suggests that at higher levels of per capita income, the adverse impact of income inequality on the infant mortality rate intensified. This result is statistically significant at the $10 \%$ level in the more inclusive specification, but it falls below the threshold as the other independent variables are dropped. The coefficients on CONFLICT and FLIT have the expected signs, but are not statistically significant. Again as expected, public health expenditure also shows an inverse relationship to variations in NPG for infant mortality rate, although the results are statistically weak.

\subsubsection{Under-Five Mortality Rate}

The regression results for the NPG in the under-five mortality rate again reveal a statistically significant adverse impact of income inequality. The Gini-income interaction is also statistically significant in both specifications, suggesting that the adverse impact of income inequality is greater in countries with higher mean incomes. CONFLICT and female literacy also have statistically significant effects, suggesting that these structural variables are important even after controlling for the effects of income inequality. Public health expenditure has a negative (i.e., favorable) effect on under-five mortality, but the relationship is not statistically significant.

\subsubsection{Stunting}

The regression results for the NPG in the rate of stunting among children under five years of age are also provided in Table 3. Here the impact of income inequality is least clear cut, with weak positive coefficients in the inclusive model but a negative coefficient in the more parsimonious model. In the latter model, female literacy is associated with less stunting and this result is statistically significant. In both models, public health expenditure is the single strongest predictor of the NPG in stunting; its estimated coefficients have the expected sign and are statistically significant at the $1 \%$ level.

\subsection{Education}

The regressions results obtained for the two education indicators - primary school enrollment and the percentage of children reaching grade five - are provided in Table 4 . In general, the regressions perform better than those for health indicators, with higher overall explanatory power as indicated by the $\mathrm{R}^{2}$ statistics. Recall that in these cases, a higher value of the NPG denotes better-than expected performance. Hence the expected signs on the coefficients are the opposite of those for the child health regressions. 
Table 4 Determinants of Education Performance Gaps

\begin{tabular}{|c|c|c|c|c|}
\hline 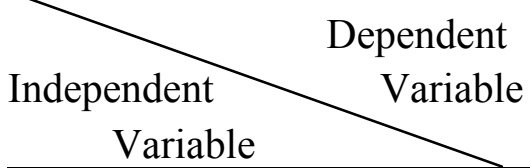 & (1) & $\mathrm{G}_{\mathrm{PEN}}$ & (1) & TRG5 \\
\hline Gini & $\begin{array}{c}0.12 \\
(0.50)\end{array}$ & - & $\begin{array}{c}-0.03 \\
(-0.10)\end{array}$ & 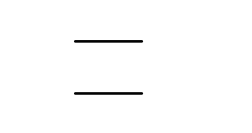 \\
\hline Gini-Income Interaction & $\begin{array}{c}-7.20 \mathrm{E}-05^{* * *} \\
(-3.83)\end{array}$ & $\begin{array}{c}-6.60 \mathrm{E}-05^{* * *} \\
(-4.10)\end{array}$ & $\begin{array}{c}-1.00 \mathrm{E}-04 * * * \\
(-4.33)\end{array}$ & $\begin{array}{c}-1.00 \mathrm{E}-04 * * * \\
(-5.15)\end{array}$ \\
\hline Female Literacy & $\begin{array}{c}0.41 * * * \\
(4.11)\end{array}$ & $\begin{array}{c}0.40 * * * \\
(4.26)\end{array}$ & $\begin{array}{c}0.38 * * * \\
(2.93)\end{array}$ & $\begin{array}{c}0.39 * * * \\
(3.93)\end{array}$ \\
\hline CONFLICT & $\begin{array}{c}-3.05 \\
(-0.84)\end{array}$ & - & $\begin{array}{c}-3.43 \\
(-0.74)\end{array}$ & $\longrightarrow$ \\
\hline Education Expenditure & $\begin{array}{l}-2.04^{* *} \\
(-1.70)\end{array}$ & $\begin{array}{l}-2.0 * * \\
(-1.67)\end{array}$ & $\begin{array}{c}-0.50 \\
(-0.32)\end{array}$ & 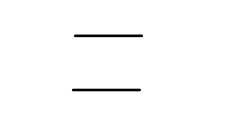 \\
\hline $\mathrm{R}^{2}$ & 0.30 & 0.28 & 0.30 & 0.33 \\
\hline $\mathrm{N}$ & 54 & 54 & 51 & 51 \\
\hline
\end{tabular}

Notes:

A positive value of $\mathrm{NPG}_{\mathrm{IM}}$ denotes higher-than-expected infant mortality rate.

$* * *=$ Significant at $1 \%$ level

$* *=$ Significant at $5 \%$ level

* = Significant at $10 \%$ level 


\subsubsection{Primary School Enrollment}

The regression results for the NPG in primary enrollment rate indicate that two structural variables, the Gini-income interaction and FLIT, have the most powerful effects, with the expected signs at statistically high levels of significance. As in the child health regressions, the adverse impact of an inequitable income distribution on the primary enrollment rate appears to be stronger at higher levels of per capita income. The coefficient for CONFLICT has the expected sign but is statistically insignificant. Contrary to expectation, the coefficient for education expenditure is negative, suggesting an inverse relationship between education expenditure and the primary enrollment performance gap. One possible explanation for this is that the data on education are not reliable. Another possibility; however, is that overall public expenditure on education in fact has failed to increase primary school enrollment rates, suggesting that it is a blunt policy instrument at best.

\subsubsection{Rate of Reaching Grade Five}

The regression results for the NPG in the percentage of children reaching grade five are similar to those for primary school enrollment. The results for the Gini-income interaction suggest that there is a highly significant relationship between the income distribution and this measure of educational performance, and that the negative impact of income inequality intensifies as income rises. The results also suggest that FLIT is highly significant in explaining variations in the rate of reaching grade five. The sign of the coefficient on education expenditure is again counter-intuitive, although in this case not statistically significant.

\subsection{WINOCENT}

Finally, I examine the determinants of variations in the aggregate child welfare indicator, WINOCENT. Table 5, presents the regression results. Recall that WINOCENT is constructed so that a higher value indicates better performance than expected solely on the basis of per capita income. In both regressions, the estimated coefficient on the Gini index indicates a statistically significant negative relationship between income inequality and the WINOCENT index. The Gini-income interaction term is also statistically significant.

The results for the other two "structural" variables, CONFLICT and FLIT, show the expected sign and are also statistically significant: CONFLICT is associated with lower levels of child welfare, and female literacy with higher child welfare. The estimated coefficient on social expenditure was positive, as expected but of weak statistical significance. FLIT and Conflict both appear as strong predictors of child welfare. In sum, these results suggest that the structural variables are the most important determinants of international variations in the aggregate measure of child welfare. 
Table 5 Determinants of WINOCENT

\begin{tabular}{l|cc}
\hline \multicolumn{1}{c|}{$\begin{array}{c}\text { WiNOCENT } \\
\text { Variable }\end{array}$} & $(1)$ & $(2)$ \\
\hline Gini & $-0.81^{*}$ & $-0.81^{*}$ \\
& $(-1.81)$ & $(-1.82)$ \\
Gini-Income Interaction & $-8.60 \mathrm{E}-05^{* *}$ & $-8.60 \mathrm{E}-05^{* *}$ \\
& $(-2.51)$ & $(-2.51)$ \\
Female Literacy & $0.41^{* *}$ & $0.43^{* * *}$ \\
& $(2.54)$ & $(2.86)$ \\
CONFLICT & $-11.51^{* *}$ & $-11.80^{* *}$ \\
& $(-2.00)$ & $(-2.10)$ \\
Social Expenditure & 0.61 & - \\
\hline $\mathrm{R}^{2}$ & $(0.52)$ & - \\
\hline $\mathrm{N}$ & 0.39 & 43
\end{tabular}

Notes:

A positive value of $\mathrm{NPG}_{\mathrm{IM}}$ denotes higher-than-expected infant mortality rate.

$* * *=$ Significant at $1 \%$ level

$* * \quad=$ Significant at $5 \%$ level

* $=$ Significant at $10 \%$ level

\section{Concluding Remarks}

Child welfare has become increasingly an important subject of analysis as well as advocacy in the last decade. The 1989 United Nations' Convention on the Rights of the Child was a particularly important catalyst in bringing children's well being to the mainstream of public debate. The fact that children cannot care for themselves places a moral obligation on the family, the community, and governments to allocate adequate 
resources to meet child needs. The UN Convention on the Rights of the Child (1989) obliges all signatories to "diminish infant and child mortality and to combat disease and malnutrition," and to "undertake such measures [to meet this obligation] to the maximum extent of their available resources.",

This paper has utilized national performance gaps in child health and education, and a holistic index of child welfare derived from them, to analyze international variations in child welfare. The use of national performance gaps as a quantitative indicator of child welfare, first introduced by UNICEF in 1993, measures how well countries perform with respect to child welfare, by comparing them to other countries with a similar level of per capita income. This allows us not only to compare performance across countries at different income levels, but also to analyze econometrically the determinants of the divergence between actual performance and that expected on the basis of income alone.

The analysis in this paper yields several conclusions. First, the results demonstrate that income distribution is a major determinant of international variations in child welfare. Unequal income distribution was found to be negatively related to the aggregate child welfare index, WINOCENT, and to have an adverse impact on all the NPGs. The impact of income distribution was statistically significant at the 5\% level for the WINOCENT, and the health performance gaps, and at the $1 \%$ level for the education performance gaps.

Second, the regressions results indicate that the deleterious impact of income inequality on child welfare is generally weaker at higher levels of per capita income, and stronger at lower income levels. This finding is consistent with the view that income inequalities have a greater impact on inequalities of capabilities - in this case, on the capabilities of children - when mean incomes are low. Based on these results it can be concluded that income redistributive policies can benefit children, especially in countries with lower levels of income.

A third conclusion that can be drawn from these results is that the female literacy rate is an important factor in determining child welfare. The level of significance of this relationship is particularly high for the educational variables. The female literacy rate can have important effects both directly, through its immediate impacts on family life, and indirectly, through its impact on the distribution of power in society. This finding reinforces the case for public policies intended to eliminate the gap between male and female children's schooling.

Fourth, the regression results indicate that the presence of armed conflict has a measurable deleterious effect on child welfare. This effect was apparent in each of the regressions, with the greater statistical significance in the case of the aggregate childwelfare index. This result implies that policies to prevent violent conflict and to promote peace-building will have a positive impact on child welfare, and that such policies can foster economic development among other ways by expanding human capabilities. In

${ }^{17}$ United Nation's 'Convention on the Rights of the Child,' articles 4 and 24. 
terms of short-term policies, this result also provides support for efforts made by international agencies, notably UNICEF, to create 'corridors of peace' for the delivery of aid to children caught in middle of civil strife and armed conflict (UNICEF 1996, p. 25).

Finally, it was found that child welfare has a positive relationship to public health expenditures. Surprisingly, however, education expenditure is found to have an inverse relationship with education performance gaps. Whether this is due to inefficiency in education expenditure or simply to the poor quality of the data on educational performance and/or expenditure is an open question.

These results have significant implications for policy. Notwithstanding the adverse impacts on child welfare of structural variables, notably income inequality, fiscal policies can make a difference. In particular, it appears that increased government expenditure on health can have a positive impact on child welfare. This has the broader implication that fiscal reallocations can foster human capabilities and thus economic development. At the same time, however, the results suggest that broader structural changes are crucial to long-term improvements in the well being of children.

In sum, the analysis indicates that both short-run "policy" variables and longer-term "structural" variables have important impacts on child welfare. Just as a holistic measure of child welfare encompasses multiple dimensions of well being, so a holistic strategy for advancing child welfare must encompass policies that address the multiplicity of factors, both short-term and long-term, that affect the well-being of children throughout the world. 


\section{References}

Andrews, S.R., J.B. Blumenthal, D.L. Johnson, A.J. Khan, C.J. Ferguson, T.M. Lasater, P.E. Malone, and D.B. Wallace, (1982) "The Skills of Mothering: A Study of Parent-Child Development Centers." In Monographs of the Society for Research in Child Development, 47(6), Serical No. 198. Chicago: University of Chicago Press.

Bairagi, R. (1980) "Is Income the Only Constraint on Child Nutrition in Rural Bangladesh?" Bulletin of the World Health Organization 58(5).

Behrman, J.R., and B.L. Wolfe (1987a) "How Does Mother's Schooling Affect the Family's Health, Nutrition, Medical Care Usage, and Household Sanitation?" Journal of Econometrics 36:185-204.

Behrman, Jere R. (1996) Human Resources in Latin America and the Caribbean, Washington D.C.: Inter-American Development Bank.

. (1987b) "Investments in Schooling in Two Generations in PreRevolutionary Nicaragua: The Roles of Family Background and School Supply." Journal of Development Economics 27(1-2):395-420.

. (1989) "Does More Schooling Make Women Better Nourished and Healthier? Adult Sibling Random and Fixed Effects Estimates for Nicaragua." Journal of Human Resources 24(4):644-663.

Boyce, James K. et al. (1999) "Power Distribution, the Environment, and Public Health: A State-Level Analysis", in Ecological Economics, Vol. 29, pp. 127-140.

Brett, R. McCallin, M. and R. O'Shea (1996) Children: The Invisible Soldiers. Geneva: Quaker U.N. Office and the International Catholic Child Bureau.

Birdsall, N. (1985) "Public Inputs and Child Schooling in Brazil.” Journal of Development Economics 18(1):67-86.

Bixby, Rosero (1983) Social and Economic Policies and Their Effects on Mortality: The Costa Rican Case, Paris: IUSSP-INED, Feb. 28 - Mar. 4.

Caldwell, J. (1979) "Education as a Factor in Mortality Decline: An Examination of Nigerian Data" in Population Studies Vol. 33, pp. 395-413.

Carvajal, M. and Burgess, P. (1978) "Socio-Economic Determinants of Foetal and Child Deaths in Latin America: A Comparative Study of Bogota, Caracas, and Rio de Janeiro", in Social Science and Medicine, Vol. 120. 
Chavez, A., R.S. Martinez, and B. Soberanes, (1995) "The Effect of Malnutrition on Human Development. A 24-year Study of Well-nourished and Malnourished Children Living in a Poor Mexican Village". In N. S. Scrimshaw, ed., Community-Based Longitudinal Nutrition and Health Studies: Classical Examples from Guatemala, Haiti and Mexico. Boston: International Nutrition Foundation for Developing Countries .

Cliff, J. and A.R. Noormahomed (1993) “The Impact of War on Children's Health in Mozambique." Social Science and Medicine 36(7): 843-848.

Cochrane, S. (1980) The Effects of Education on Health, World Bank Staff Working Paper No. 405, Washington, D.C.: World Bank.

Dalirazar, Nasrin (2002) "An International Index of Child-Welfare", Working Paper, Political Economy Research Institute. University of Massachusetts, Amherst, MA, June.

De Carvalho, J. and Wood, C. (1978) "Mortality, Income Distribution, and Rural-Urban Residence in Brazil" in Population and Development Review, 4(3).

Dodge, C.P. (1991) "Child Soldiers of Uganda and Mozambique" in C.P. Dodge, and M. Raundalen (eds) Reaching Children in War: Sudan, Uganda and Mozambique. Uppsala: Sigma Forlag.

D’Souza, S. and Bhuiya, A. (1982) "Socio-Economic Mortality Differentials in a Rural Area of Bangladesh" in Population and Development Review 8(4).

Farrell, J., and E. Schiefelbein, (1985) "Education and Status Attainment in Chile: A Comparative Challenge to The Wisconsin Model of Status Attainment." Comparative Education Review 29(4):490-506.

Flegg, A. (1982) "Inequality of Income, Illiteracy and Medical Care are Determinant of Infant Mortality in Underdeveloped Countries", in Population Studies 36(3).

Garbarino, J. and K. Kostelny (1996) "The Effects of Political Violence on Palestinian Children's Behavioral Problems: A Risk Accumulation Model." Child Development 67(1): 33-45.

Gertler, P., P. Glewwe, (1990) "The Willingness to Pay for Education in Developing Countries: Evidence from Rural Peru." Journal of Public Economics 43(3): 251:275.

Goldson, E. (1996) "The Effect of War on Children." Child Abuse and Neglect 20(9): 890-819. 
Grantham-McGrego, S., C. Powell, S. Walker, and J.H. Himes (1991) "Nutritional Supplementation, Psychosocial Stimulation, and Mental Development of Stunted Children: The Jamaican Study" Lancet 338:1-5.

Gray, S., and K. Ruttle, (1980) "The Family-Oriented Home Visiting Program: A Longitudinal Study.” In Genetic Psychology Monographs 102: 299-316.

Guerra, F. (1981) "Determinants of Infant Mortality in Panama" CELADE Series D. No. 99.

Harbert, L., and P.L. Scandizzo, (1982) Food Distribution and Nutrition Intervention: The Case of Chile, Staff Working Papers No. 512. Washington, D.C.: World Bank.

Hauser-Cram, P. (1983) A Question of Balance: Relationship Between Parents and Teachers. Doctoral Dissertation, Harvard Graduate School of Education.

Heckman, J.J., and V.J. Hotz, (1986) "The Source of Inequality for Males in Panama's Labor Market." Journal of Human Resources 21(4):507-42.

Hick, S. (2001) “The Political Economy of War-Affected Children." Annals of the American Academy on Social Sciences 575, May.

Kagitcibasi, C., and I. Savasir, (1988) "Human Abilities in the Eastern Mediterranean." In S.H. Irvine, and J.W. Berry, (eds.) Human Abilities in Cultural Context. Cambridge: Cambridge University Press.

Kagitcibasi, Cigdem (1997) "Parent Education and Child Development." In M.E. Young, ed., Early Child Development: Investing in Our Children's Future. Amsterdam, Holland: Elsvier.

. (1993) "A Model of Multipurpose Non-Formal Education: The Case of the Turkish Early Enrichment Project." In L. Eldering, and P. Leseman, (eds.) Early Intervention and Culture. The Hague, Netherlands: United Nations Educational, Scientific, and Cultural Organization.

. (1996) Family and Human Development Across Cultures: A View from the Other Side. Hillsdale, N.J.: Lawrence Erlbaum Associates.

Kakwani, N. (1993) "Performance in Living Standards An International Comparison", Journal of Development Economics Vol. 41, pp. 307-336.

Kawachi, Ichiro et al. (1997) "Social Capital, Income Inequality, and Mortality," American Journal of Public Health, 87(9) pp.1491-1498.

King, E.M., and R. Bellow, (1988) Education Policy and Schooling Levels in 
Peru. Washington, D.C.: World Bank. Mimeo.

Lynch, John et al. (1998) "Income Inequality and Mortality in Metropolitan Areas of the United States" American Journal of Public Health, 88(7) pp. 1074-1080.

Machel, Graca. (1996) Impact of Armed conflict on Children. United Nations Report No. A/51/306. Available at http://www.unicef.org/graca.

Machel, Graca. (2000) The Impact of Armed Conflict on Children: A Critical Review of Progress Made and Obstacles Encountered in Increasing Protection for WarAffected Children. Winnipeg: Government of Canada. Available at http://www.waraffectedchildren.gc.ca/machel-e.asp.

Martin, L et al. (1985) "Covariates of child Mortality in the Philippines, Indonesia, and Pakistan: A Comparative Analysis" in Population Studies

McCord, Collin et al. (1980) Death Rate, Land and the Price of Rice 1975-1978, Evaluation Unit Report No. 4, Companiganj Health Project, Noakhali, Christian Commission for Development in Bangladesh.

Mosley, W.H. (1983) Will Primary Health Care Reduce Infant and Child Mortality? A Critique of Some Current Strategies, with Reference to Africa and Asia, Paris: Institut National d'Etudes Demographiques (INED).

Myers, Robert (1992) The Twelve Who Survive: Strengthening Programmes of Early Childhood Development in the Third World. London: Routledge.

Nag, M. (1981) Impact of Social Development and Economic Development on Mortality: A Comparative Study of Kerala and West Bengal, Working Paper No. 78, the Population Council.

Olds, D.L., C.R. Henderson, R. Chamberlain, and R. Tatelbaum, (1986) "Preventing Child Abuse and Neglect: A Randomized Trial of Nurse Home Visitation." In Pediatrics 78: 65-78.

Pollitt, E., and K. Gorman, (1989) "Long-term Developmental Implications of Motor Maturation and Physical Activity in Infancy in a Nutritionally At Risk Population". In B. Schurch, and N.S. Scrimshaw, eds., Activity, Energy Expenditure and Energy Requirements of Infants and Children, IDECG (International Dietary Energy Consultative Group) Workshop, Nov. 14-17, Cambridge, M.A.

Pollitt, E., and S-Y Oh, (1994) "Early Supplementary Feeding, Child Development, and Health Policy" Food and Nutrition Bulletin 15(3):208-14.

Pollitt, E., W.E. Watkins, and M.A. Husaini, N.D. "Three-month Nutritional 
Supplementation among Indonesian Infants and Toddlers Benefits Memory Function Eight Years Later". Submitted to the American Journal of Clinical Nutrition, Forthcoming.

Ressler, E.M., J.M. Tortorici, and A. Marcelino (1993) Children in War: A Guide to the Provision of Services. New York: UNICEF.

Rodriguez, G.G. (1983) Final Report: Project CAN PREVENT. San Antonio, Texas: Avance.

Rodriguez, G.G., and C.P. Cortez, (1988) "The Evaluation Experience of the Avance Parent-Child Education Program." In H.B. Weiss, and F.H. Jacobs, (eds.) Evaluating Family Programs. New York: Aldine de Gruyer.

Slaughter, D. (1983) "Early Intervention and its Effects on Maternal and Child Development." Monographs of the Society for Research in Child Development 48(4). Serial No. 202.

Super, C., M. Herrera, and J. Mora, (1990) "Long-Term Effects of Food Supplementation and Psychosocial Intervention on the Physical Growth of Colombian Infants at Risk for Malnutrition," in Child Development, Vol. 61: 29-49.

Thomas, D. and J. Strauss, (1992) "Prices, Infrastructure, Household Characteristics and Child Height." Journal of Development Economics, Vol. 39: 301-331.

Thomas, Duncan (1990) "Intra-Household Resource Allocation: An Inferential Approach" Journal of Human Resources, Vol. 25 (4): pp. 635-664.

Thomas, D., J. Strauss, and Maria Helena Fernandes Henriques da T. (1990) "Child Survival, Height for Age, and Household Characteristics in Brazil." Journal of Development Economics, Vol. 33 (2): 197-234.

Travers, J., M.J. Nauta, N. Irwin, B. Goodson, J. Singer, and C. Barclay, (1982) The Effects of a Social Program: Final Report of the Child and Family Resource Program's Infant-Toddler Component. Cambridge, MA: Abt Associates, Inc.

United Nations, Expert Group on Mortality and Health Policy,(1983) Findings of the World Fertility Survey on Trends, Differentials and Discriminants of Mortality in Developing Countries, Paper for the International Conference on Population, Rome: UN-DIESA.

UNESCO (2000) World Education Report 2000. Paris: UNESCO.

UNICEF (1981) Analysis of the Situation of Children in India, New Delhi: UNICEF.

UNICEF (1993) Progress of Nations 1993. New York, N.Y.: UNICEF 
UNICEF (1993) Psychosocial Programme: Emergency Operations in Former Yugoslavia Kit. New York: UNICEF.

UNICEF (1996) Progress of Nations 1996. New York, N.Y.: UNICEF.

UNICEF(2000) State of the World's Children. New York: UNICEF.

Waldman, R.J. (1992) "Income Distribution and Infant Mortality.” Quarterly Journal of Economics 107(4):1283-302.

Wolfe, B., and J. Behrman, (1983) "Is Income Overrated in Determining Adequate Nutrition?" Economic Development and Cultural Change 31(3):525-49

World Bank (2000) World Development Indicators 2000. Washington, D.C.: World Bank.

World Health Organization (2000a) World Health Report 1999. Geneva: World Health Organization.

World Health Organization (2000b) Global Database on Child Growth and Malnutrition at http://www.who.statistics

Young, Mary (1995) Investing in Young Children. Washington, D.C.: The World Bank. 